\section{SCIENTIFIC MAN-POWER IN BRITAIN}

T HE report of the Committee on Scientific Man-Power*, appointed by the Lord President of the Council on December 9, 1945, under Sir Alan Barlow as chairman, "to consider the policies which should govern the use and development of our scientific man-power and resources during the next ten years", points out that the problem falls into two distinct parts. The immediate tasks are the return of qualified men of science from the Forces to civil life and the civilian occupations in which they have been serving the Forces; to guide them into peace-time occupations according to the needs of reconstruction; and to make good the physical damage which war has inflicted on the universities and research establishments. The longer-term problem is the provision of sufficient qualified men of science to meet the nation's requirements during the reconstruction period and after. In neither respect is a narrow view taken of the field of activity of scientific workers: the Committee believes that much benefit would result from the wide diffusion of scientific knowledge and scientific methods through all spheres of activity. Moreover, since the Committee is satisfied that the demand for scientific workers over the next few years will exceed the possible supply both as a whole and in each major branch of science, it has not attempted to deal with the separate needs for each branch of science.

Dealing first with the immediate problem, the Committee believes that the procedure for expediting the return of scientific men to civil life is adequate, and it has no improvements to recommend. It is satisfied that military commanders on the spot are not exercising unreasonably their power to retain a man on grounds of military necessity. It emphasizes the vital function of the Appointments Department of the Ministry of Labour and National Service, saying that the fullest possible use should be made of its facilities. Since, moreover, the scientific man in industry is most fruitfully employed as a member of a balanced team of men of science, engineers, technical assistants and other ancillary staff, where the shortage of man-power is almost as acute as among scientific workers themselves, applications for the release of experienced assistants under Class B should be considered sympathetically where it can be shown that the work of a scientific worker will be held up if release is not granted. Everything possible should be done to meet the immediate needs of the universities for accommodation, particularly of those that have suffered war damage.

The longer-term problem occupies the bulk of the report, and the Committee's analysis of the supply and demand situation leads to the conclusion that it is unlikely that the nation has at its disposal to-day more than 55,000 qualified scientific workers, whereas a minimum demand of about 70,000 in Great Britain itself and in the Colonial services, including 30,000 teachers, is predicted for 1950 . On the expansion envisaged in the returns furnished by the universities to the University Grants Committee, it is unlikely that the trained scientific man-power available in 1950 will exceed 60,000 , and it may be no more than 55,000 . Review of demand over a five-year period is, of course, inadequate as a basis for recommenda-

* Report of the Committee on Scientiflc Man-Power. (Cmd. 6824.) (London: H.M. Stationery Office, 1946.) $6 d$. tions, where three years is the minimum period of training; but taking all known factors into account, the Committee estimates that by 1955 the demand for scientific workers will be not less than 90,000 , and that under present plans we can expect no more than 64,000 to be available. Accordingly, it is essential that the output of graduates in science should be increased very much above the level of expansion at present contemplated by the universities of Britain : the immediate aim should be to double the present output, giving us approximately 5,000 recruits every year at the earliest possible moment.

Turning next to this question of doubling the output of scientific workers, the Committee is satisfied that there is an ample reserve of intelligence in Great Britain to allow both a doubling of the university numbers and a simultaneous raising of standards. Only about one in five of the boys and girls who have intelligence equal to that of the best half of the university standards actually reach the universities, and the great majority of the intelligent persons who do not reach the universities are from the elementary schools. Furthermore, even doubling the total student population of British universities would leave the country behind a number of European countries and the United States of America in the relative provision it makes for higher education.

The Committee also supports the recommendation of the Percy Committee on Higher Technological Education that full-time technological courses of university degree standard should be developed at a selected number of technical colleges, and it supports Lord Eustace Percy's opinion that the Government should treat the colleges of technology as a group and develop among them some major university institutions. It also welcomes the stress laid on the provision of post-graduate research courses in such colleges and any arrangements to raise the currency of technological qualifications. The universities must also recognize their responsibility for training a high proportion of first-class technologists, and expansion in the output of graduates should not be less proportionately in technology than in pure science. Urgent consideration should be given to the development of two or three institutes of technology, preferably in university cities, to maintain the highest possible standards of post-graduate study and research. Equally, the Committee deprecates any attempt to meet the increased demand for scientific men and technologists at the expense of other subjects, or to give any preference to science students over arts students in such matters as military service. It attaches very great importance to the atmosphere of an association of men and women which takes all knowledge as its province and in which all branches of learning flourish in harmony.

Reviewing next the capacity to expand of the universities of Britain, the Committee stresses the great importance of the universities being assured in future of adequate and continuing assistance from the Exchequer towards any project for which good cause is shown. It is confident that even in the next few years there will be no lack of trained students to fill the expanding universities; but the Committee comments trenchantly on the inadequacy of both available buildings and the supply of suitable teachers. In regard to the former, it suggests that the possibility of using neighbouring country houses or vacated military camps as temporary annexes might be explored or the shift system extended to make fuller use of lecture rooms and laboratories. 
In regard to staff, the Committee is not convinced that if the universities started a vigorous recruiting campaign, an adequate supply of science teachers of sufficient calibre would not be forthcoming. It recommends that the universities should make a comprehensive survey of their staff requirements in the light of the expansion proposed, that all university vacancies should be notified as a matter of routine to the Appointments Department of the Ministry of Labour, and that the universities should consider the possibility of taking an increased proportion of their staff direct into the lecturer grade. The Committee is opposed to any attempt to increase the student population by adding substantial additional teaching responsibility to the individual members of a faculty : the average teacher should have more and not less opportunity for his own research than he has had in the past

In this belief that, once the urgency and importance of the nation's need for more graduates are widely appreciated, and provided the financial misgivings of the universities are removed, the obstacles to their expansion in the immediate future need not prove insuperable, the Committee considers the problems of individual universities and their response to the idea of expansion. Regretting that neither Oxford nor Cambridge has suggested any permanent expansion in its student body, the Committee considers that these two ancient universities should regard it as a duty to make some contribution towards meeting the nation's requirements, possibly by enlarging some of the smaller of the existing colleges and the foundation of one or more new colleges. There is some scope for expansion in the student population of the University of London, although expansion may involve a policy of decentralization. A really substantial expansion of the English civic universities and the University of Wales depends to a considerable extent on these universities being able to compete with Oxford, Cambridge and London for the limited supply of talented students. The present system tends to concentrate the major proportion of State and county scholars into three universities and is fundamentally bad. The improvement of amenities such as halls of residence is one among many ways in which the civic universities can help themselves, but the educational authorities should consider urgently a revision of the scholarship system.

The existing University Colleges of Nottingham, Southampton, Exeter, Hull and Leicester should be able to make a substantial contribution towards filling the remaining gap and should aim at earning full university status at the earliest possible date. There are also several large centres of population in which new university colleges could profitably be established. The Committee thinks that there is still scope for expansion, though on a smaller scale, in the Scottish universities; but it also suggests that early consideration be given to the foundation of at least one new university which would give to the present generation the opportunity of leaving to posterity a monument of its culture. Finally, touching on the quality of science teaching, the Committee emphasizes its dependence on the quality of research and records its opinion that, as an essential part of any balanced expansion in the science faculties, there should be an expansion in research schools for training purposes apart from the needs of the students, and an increase in the financial grants that are made specific. ally towards research by university staffs.
When all possible measures have been taken to expand the output of graduates, Great Britain will still be seriously short of scientific workers in 1950 , and is unlikely to have an adequate supply by 1955. The Committee incidentally records the view that if the intellectual standard of graduates is not to suffer, science students should be allowed, if they wish and if there is room for them, to complete their full course before doing their period of military service; but it also recommends that some system of priorities should be established to secure the best use of our limited supply of men of science. During the reconstruction period, this order of preference should be, first, teaching and fundamental research; secondly, civil science, both Government and industrial; and thirdly, defence science. It is important, however, to maintain an adequate nucleus of able scientific workers working on the problems of defence, and the order of priority set out should be kept under constant review by the Government. As one means of implementing this order of priority, the attractions of an academic career should be improved. Provision of more secretarial assistance and office machinery for university teachers would not only contribute to this end but also would increase materially the efficiency of the universities. Looking at the position after 1955, the Committee does not think that the universities need fear that expansion of their facilities to provide an output of 3,000 graduates in science each year would leave them with excessive staffs and accommodation once the demand for qualified scientific workers has steadied.

No indication of the cost of implementing these proposals is attempted in the report, but the Committee insists that acceptance of the proposals by the Government must not involve any infringement of the independence of the universities. Such independence, in the Committee's view, is not inconsistent with a greater degree of co-ordination between university policy and the needs of the country than has existed in the past. The Government's instrument in any expansion programme should be the University Grants Committe日, which should increasingly concern itself with positive university policy in Britain, and it may be desirable for this purpose to revise its terms of reference and strengthen its machinery.

\section{OBITUARIES \\ Dr. F. Crowther}

Dr. Frank Crowther, chief plant physiologist in the Department of Agriculture of the Sudan Government, died on April 11, at the early age of forty, after a very brief illness, during his first post-war leave.

$\mathrm{He}$ was educated at St. Albans School and entered the Imperial College of Science and Technology in 1923, graduating in botany with honours in 1926. The next two years were devoted to research in plant physiology; his work broke new ground, and established the differential manurial response of varieties of barley, and the inheritance of specific efficiencies in the utilization of individual nutritive elements. During this period Dr. Crowther was closely associated with me, and acquired, at first hand, knowledge of the methods of growth analysis which were at that time being developed. In $1928 \mathrm{Dr}$. Crowther accompanied me to the Sudan, and was appointed as plant physiologist at the Gezira Research Farm soon after his arrival. Work was begun on the analysis of the 